Quarterly Journal of the Geological Society

\title{
The Pseudotachylyte of Parijs (Orange Free State), and its Relation to 'Trap-Shotten Gneiss' and 'Flinty Crush-Rock'
}

S. James Shand

Quarterly Journal of the Geological Society 1916, v.72; p198-221.

doi: 10.1144/GSL.JGS.1916.072.01-04.12

$\begin{array}{ll}\begin{array}{l}\text { Email alerting } \\ \text { service }\end{array} & \begin{array}{l}\text { click here to receive free } \\ \text { e-mail alerts when new articles } \\ \text { cite this article }\end{array} \\ \begin{array}{l}\text { Permission } \\ \text { request }\end{array} & \begin{array}{l}\text { click here to seek permission } \\ \text { to re-use all or part of this } \\ \text { article }\end{array} \\ \text { Subscribe } & \begin{array}{l}\text { click here to subscribe to } \\ \text { Quarterly Journal of the } \\ \text { Geological Society or the Lyell } \\ \text { Collection }\end{array}\end{array}$

\section{Notes}

(C) The Geological Society of London 2014

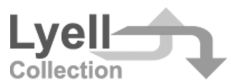


10. The Pseudotachylyte of Parijs (Orange Free State), and its Relation to 'Trap-Shotten Greiss' and 'Flinty Crush-Rock.' By S. James Shand, D.Se., F.G.S., Professor of Geology in the University of Stellenbosch. (Read March 22nd, 1916.)

\section{[Plates XVI-XIX.]}

Contents.

\begin{tabular}{|c|c|}
\hline I. Introduction & $\begin{array}{c}\text { Page } \\
198\end{array}$ \\
\hline II. Occurrence in the Field & 199 \\
\hline III. Microscopic Characters of the Pseudotachylyte. & 206 \\
\hline IV. The Case for the Igneous Origin of the Veins & 208 \\
\hline 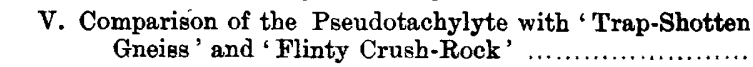 & 209 \\
\hline VI. The Chemical Composition of the Pseudotachylyte ....... & 213 \\
\hline VII. The Case against an Igneous Origin & 215 \\
\hline VIII. Conclusion . & 216 \\
\hline IX. Literature & 217 \\
\hline Appendix (Chemical Analys & 217 \\
\hline
\end{tabular}

\section{INTRODUCTION.}

Is the year 1913 I received from a former student of mine, Mr. P. H. S. De Wet, a consignment of rock-specimens from the neighbourhood of Parijs (O.F.S.). Among these were many pieces of a dense black rock, which, I was informed, occurs very abundantly in veins and networks in the granite. The characters of this rock seemed so remarkable that $I$ took an early opportunity of visiting Parijs myself, in order to study the phenomena in the field. As a result of my observations, I formed the opinion that the black veins were intrusions of basic magma which had entered the granite by a process of stoping, accompanied by corrosion and solution; and a paper embodying this conclusion was communicated to the Geological Society in November 1914, an abstract of it appearing in the Proceedings of the Society for that month (No. 964). After the manuscript had left my hands, I became aware for the first time of the work of Sir Thomas Holland and his colleagues of the Geological Survey of India on the 'trap-shotten gneiss' of Salem, Madras, and I could not fail to be struck by the resemblance between some of the phenomena there described and those observed by me. My attention was next turned to the 'flinty crush-rocks' of the Cheviot Hills and other parts of Scotland, which were also at one time held to be of igneous origin. By the kindness of Dr. Flett, the late Dr. Clough, and Mr. E. B. Bailey, I was enabled to study hand-specimens and sections of a large number of these rocks; and although, on comparing them with my own material, 
I found the differences to be at least as numerous as the resemblances, it became clear that I must reconsider the features of the Parijs occurrence in the light of the evidence derived from other regions. Parijs was accordingly revisited during 1915, and such fresh information and illustrations as were gained have been embodied in the account which is now presented.

It should be explained that the name pseud otachylyte has been adopted in recognition of the fact that these rocks have a great similarity to tachylyte, also that such rocks have been mistaken for trap and tachylyte in Scotland and India as well as in South Africa, and for the further reason that no more suitable name is in existence. 'Trap-shotten gneiss' denotes the entire complex of intrusion and intruded rock, and is misleading in view of the fact that the intrusive part is not certainly 'trap' at all; while 'flinty crush-rock' begs the question-as regards the Parijs rocks, at least.

\section{OccurRence in the Field.}

The township of Parijs lies upon the northern portion of the Vredefort granite-mass and on the southern bank of the Vaal River. The granite, which has an outcrop of some 400 square miles, has generally been regarded as Archæan (that is, pre-Witwatersrand), and appears as such on Dr. F. H. Hatch's map of the Transvaal; but Dr. Molengraaff, and more recently Mr. F. W. Penny, have held that this granite is in reality intrusive in the Witwatersrand System. No detailed survey of the region has yet been made.

The 'granite' in the neighbourhood of Parijs is a streaky granitic gneiss, composed of red and grey elements. Sometimes the red forms patches and streaks within the grey, elsewhere the grey matter is similarly enveloped by the red, or again the two elements may constitute alternate bands. The red matter often forms veins and bands of coarse pegmatite which run parallel to the direction of foliation of the grey rock, but in other cases such veins cut sharply across the foliation. These pegmatites are occasionally very coarse-grained graphic granites. When extensive exposures are studied, it becomes evident that the red portion is of later consolidation than the rest of the rock. Isolated 'floaters' of banded grey paragneiss can be found embedded in the red granite; and, to my mind (although I have not made a special study of the gneissgranite), the matter is susceptible of one interpretation only, as follows:-- the grey facies of the granitic gneiss results from impregnation, metamorphism, and eventual assimilation of sedimentary country-rock by the ascending magma, while the red is the residual portion of the same magma. Probably neither part reproduces the initial composition of the magma exactly.

The red bands are composed essentially of quartz and felspar, with a very small proportion of biotite. Cleavage-pieces of the red felspar show it to be a true orthoclase; the red coloration is 
unevenly distributed, and is especially intense in the neighbourhood of cracks. 'The larger crystals often pass externally into micropegmatite. The grey bands contain much oligoclase with practically straight extinction, also a variable but generally large proportion of biotite which often exceeds 50 per cent. I have not observed any hornblende in the few slices that $I$ have cut; but at the weir, 2 miles above the township, bands of a bright-green amphibolite occur in the granite.

The special interest of the district attaches, not to the granitegneiss, but to a remarkable system of veins of apparent tachylyte which intersect the granitic rocks everywhere throughout the area north of Vredefort. (Of the southern portion of the area, where exposures of the granite seem to be much less numerous, 1 am unable to speak. The best exposures are seen in the bed and banks of the Vaal, where the scour of the running water cleans and smooths the rock-surfaces; the veins then show up jet-black and exhibit a highly polished surface, thus affording a strong contrast to the rougher grey surface of the granite. Elsewhere they weather grey or greenish, and are then difficult to distinguish from the granite. On each of my visits I took a large number of photographs of these veins, but many of the exposures were so difficult to 'catch' (on account of their awkward situations, irregular surfaces, slight colour-contrasts, and so on) that I found it desirable to supplement my photographs by scale-drawings, some of which are reproduced herewith.

The highly irregular, branching intrusion of Pl. XVI was exposed in a deep cutting made for one of the piers of the new bridge; the rock-face shown is about 7 feet high, which will give a measure of the dimensions of the intrusion. This cutting has since boen filled up. The photograph reproduced in Pl. XVII, fig. 1 was obtained in another excavation near the first; it shows a vein turning from a vertical to a nearly horizontal plane and thinning out. The width of the vein is 6 inches at the centre of the photograph. The detail of the blind end of this vein is shown in text-fig. 8 (p. 203). Pl. XVII, fig. 2 shows a large block which has been thrown out by blasting operations at the weir, above the town ; the entire block is only a portion of a wide dyke of pseudotachylyte. The floaters of granite which are embedded in the dark base are so numerous and so perfectly rounded that the rock resembles in appearance a sedimentary conglomerate. This is a most remarkable specimen, and, despite its weight, which must be about a ton, one would like to see it removed entire to a museum.

The characteristic features of the intrusions, as seen in the field, are summarized in the following paragraphs:-

The veins are utterly irregular in form, direction, and thickness (textfigures 6, 7, 10-13 ; Pl. XVI).

They have every inclination from vertical (Pl. XVI) to borizontal (Pl. XVII, fig. 1), and they strike towards all points of the compass.

They change their direction again and again, and often follow sinuous. 
Fig. 1.-Blind veins, above the boathouse.

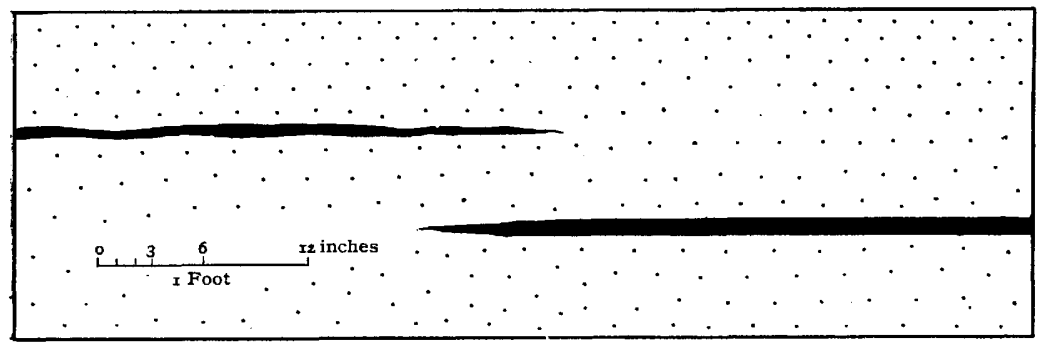

[The one on the right can be traced for about 7 feet; it runs perfectly straight, and is 1 inch wide. Within 5 inches it thins out and terminates.]

Fig. 2.-Branching, and a blind vein, seen near the boathouse.

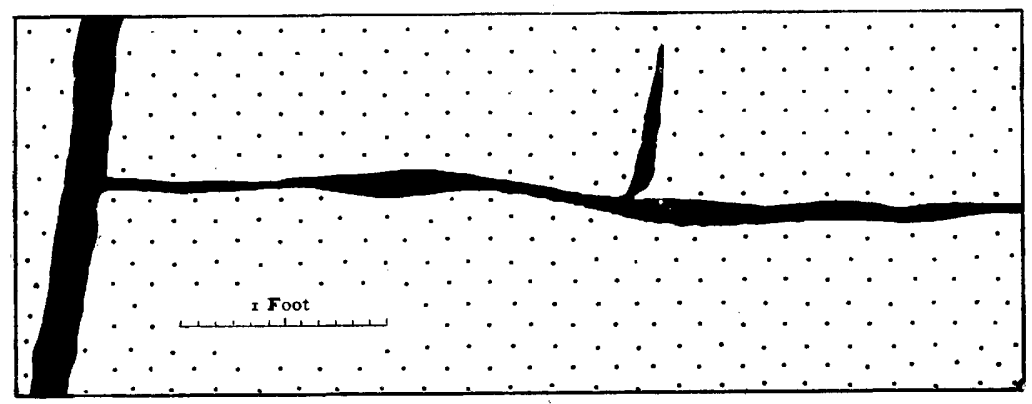

Fig. 3.-Branching and blind veins, near the boathouse.

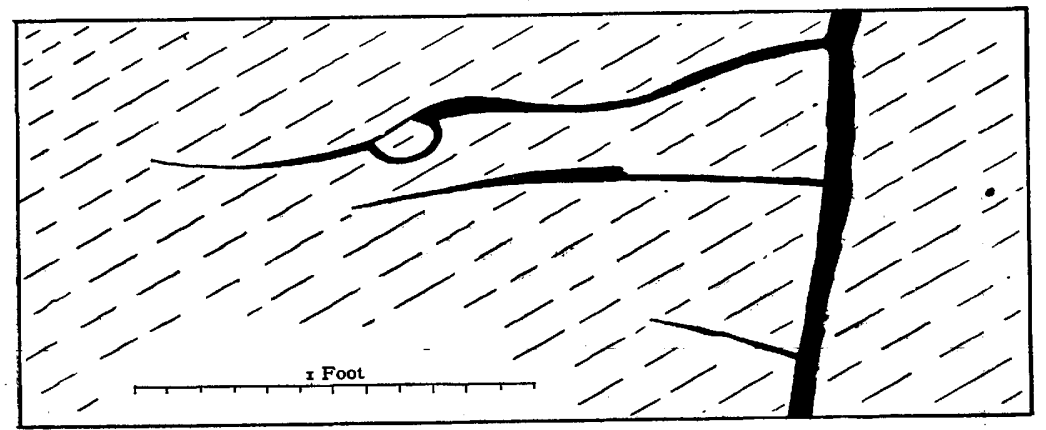

[The broken lines indicate the foliation of the granite.] 
Fig. 4.-A thin vein ( $\frac{1}{8}$ to $\frac{1}{4}$ inch) of pseudotachylyte following the margin of a pale band in granite-gneiss, in part breaking across it and sending venules into it ; 200 yards above the boathouse.

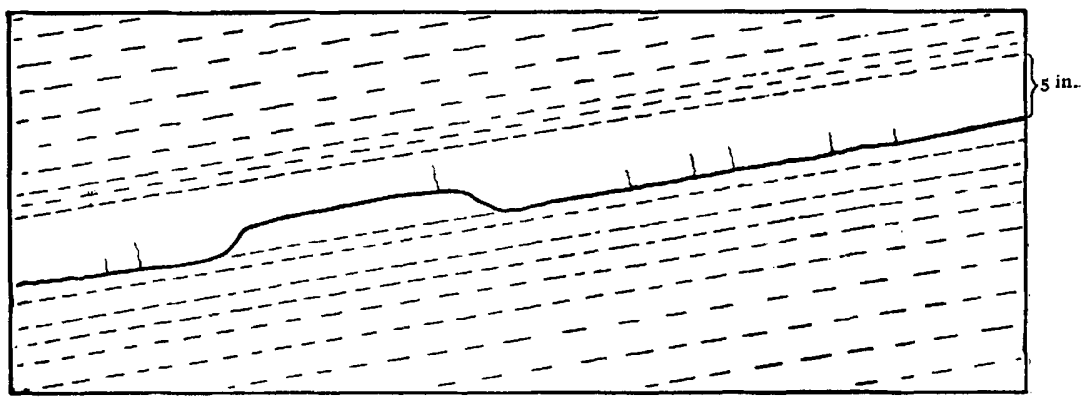

Fig. 5.--A pegmatite vein faulted 2 inches by the pseudotachylyte.

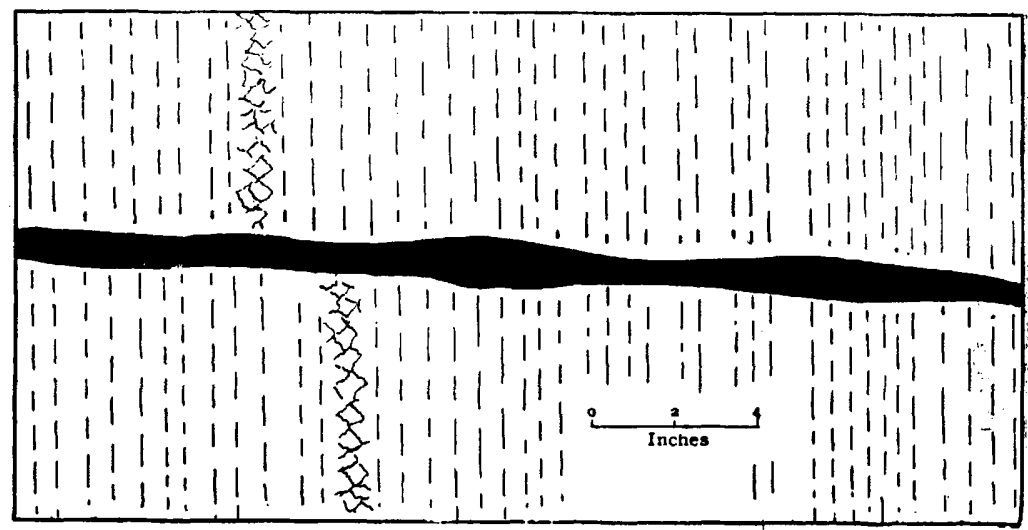

Fig. 6.-Pseudotachylyte a quarter of a mile below the bridge.

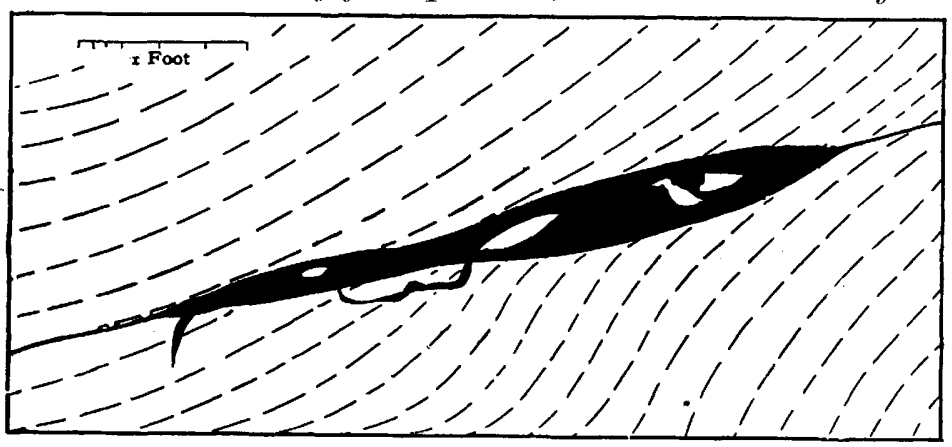

[The broken lines indicate the foliation of the granite.] 
Downloaded from http://jgslegacy.lyellcollection.org/ at National University of Singapore on June 12, 2014

Fig. 7.-Pseudotachylyte a quarter of a mile below the bridge.

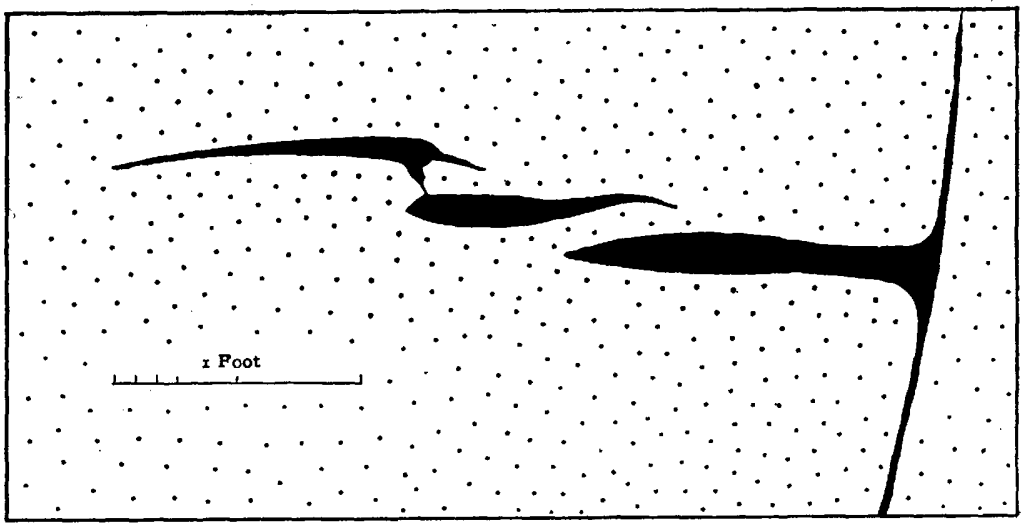

Fig. 8.-The vein shown in Pl. XVII, feathering out at its end. Cutting below the bridge.

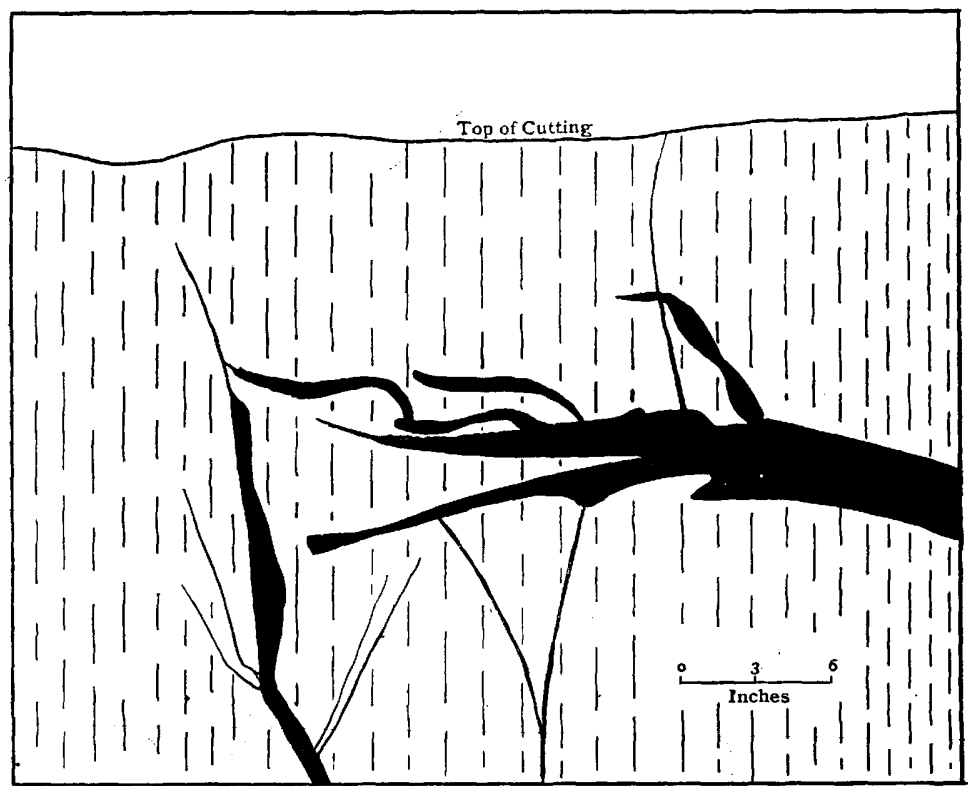


Fig. 9.-A wavy band cutting across the foliation of the gneiss, at the end of the blind intrusion illustrated in Pl. XVII. Vaal River Bridge.

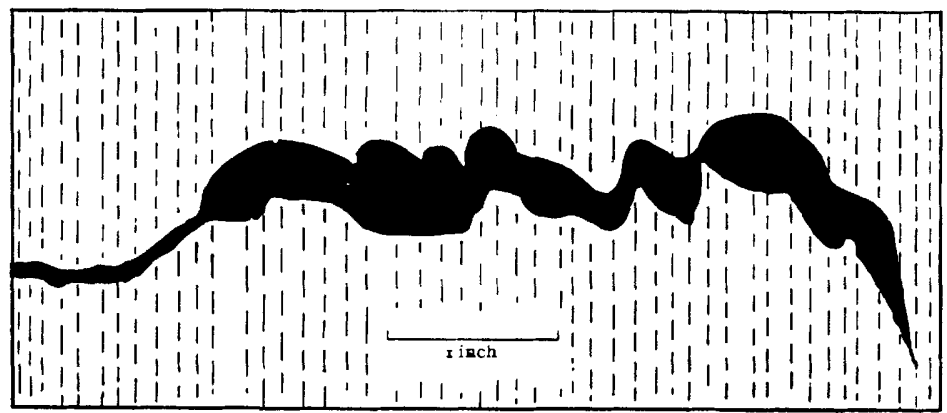

Fig. 10.- Vrin seen below the bridge.

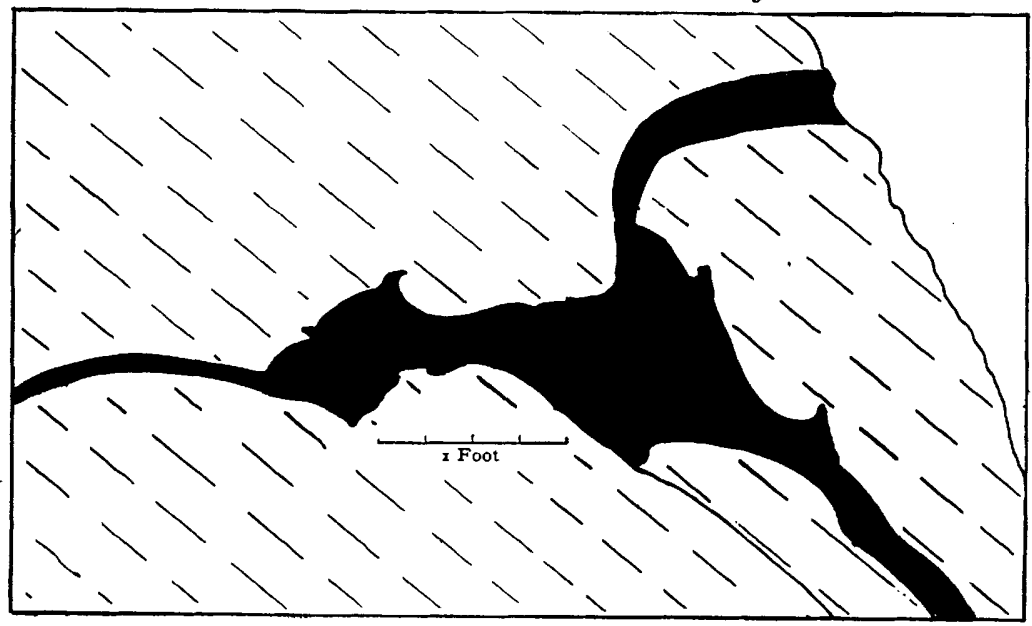

Figs. 11 \& 12.-Veins seen 200 yards above the boathouse.

11.

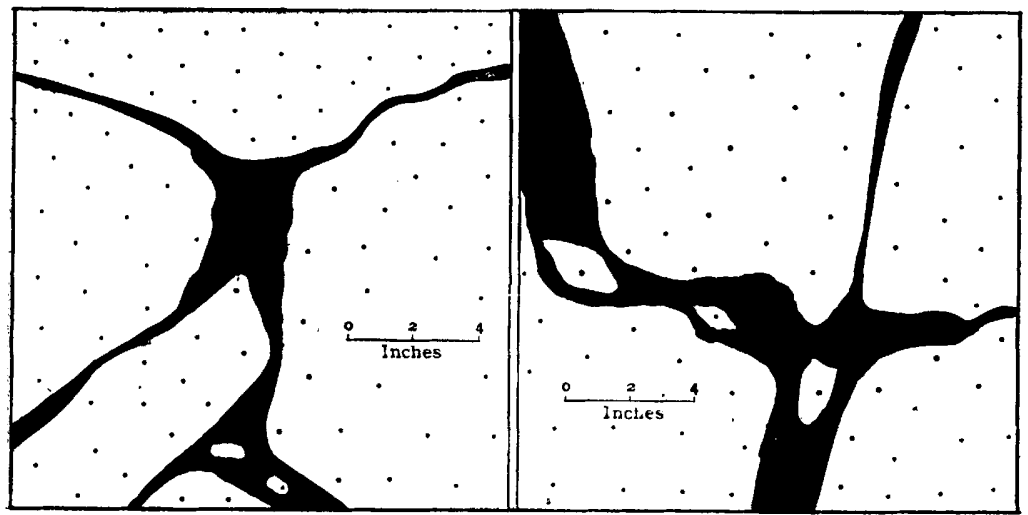


Fig. 13.- Pseudotachylyte 200 yards above the boathouse.

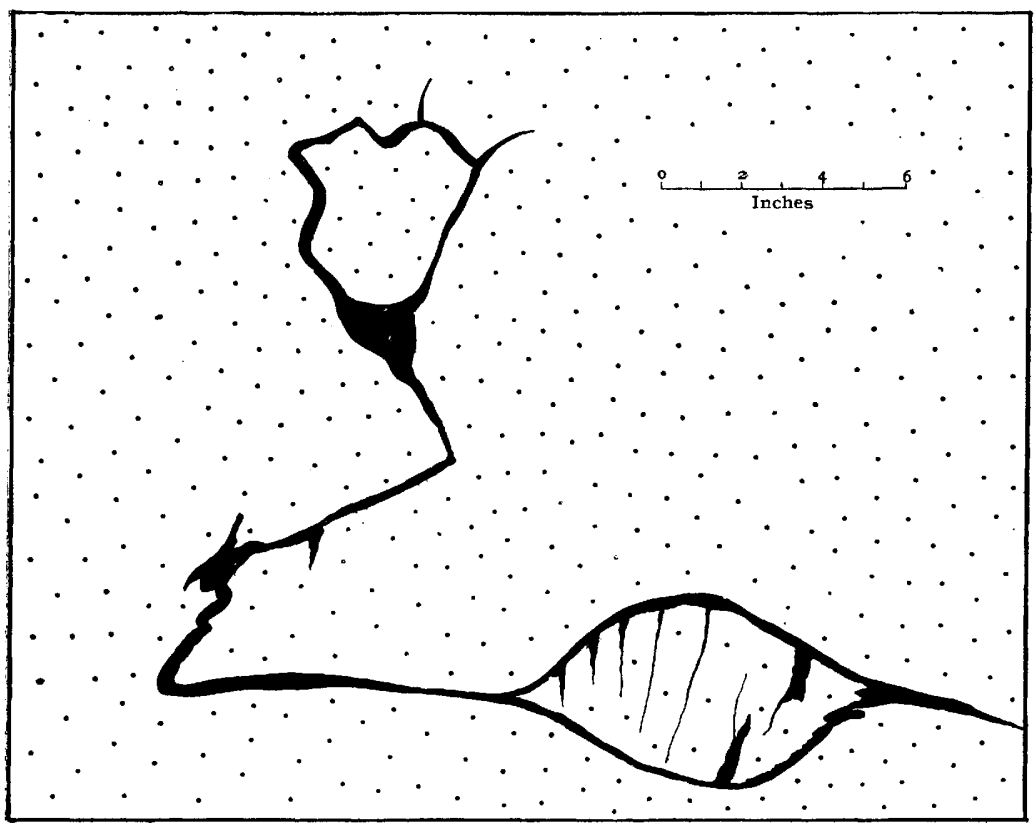

courses (text-figures 2, 3, 9-13) and their direction is entirely independent of the foliation of the granite (text-figures $3,5,6,8,10$ ).

They thicken and thin repeatedly and rapidly (text-figures $6,7,9,10-12$ ), give off branches at high and low angles (text-figures 2-4, 7, 8, 10-12), and often anastomose in the most complicated way (text-figures 10-12).

In innumerable cases they thin out and terminate blindly (text-figures 1-3, 7, 8, \& Pl. XVII, fig. 1).

The contact with the surrounding granite, as seen with the naked eye, is perfectly abrupt. The granite is never sheared parallel to the course of the veins, its texture remains unchanged, and the felspars continue to show large bright cleavage-faces and straight twinning lamellæ, right up to the surface of contact (Pl. XIX, fig. 1).

The junction-line is often nearly straight for distances of many feot, especially in the case of those veins which are not more than a few inches thick (text-figures $1,2,4,5, \& \mathrm{Pl}$. XVII, fig. 1) ; in other cases it is strongly serrated (Pl. XVI).

The veins vary in width from a fraction of an inch up to 2 or 3 feet; but in the thicker veins there are always numerous inclusions or floaters of granite which occupy a large proportion of the stated width, and the black base is often reduced to the role of a mere cement for the floaters (Pl. XVI, \& Pl. XVII, fig. 2). The floaters range from boulders a couple of feet in diameter down to minute grains, and they are far more frequently rounded or turbinate than angular (Pl. XVII). In an average sample about 20 or 25 per cent., but in some cases (Pl. XVII, fig. 2) as much as 80 per cent., of the contents of a vein consists of boulders and fragments visible to the naked eye.

$\because$ The black base in which the granite floaters are embedded is a compact black rock, like a microcrystalline basalt or tachylyte, capable of taking on a high polish. Apart from grains of quartz and felspar derived from the granite, 
no constituent of the black rock can be recognized even with a lens, nor is it possible to say whether the rock is crystalline or vitreous.

It is in most cases quite impossible to determine whether the veins act as faults. Sometimes a movement of one side of the vein, amounting to not more than 2 inches, can be proved (text-fig. 5, p. 202), but no proof of great displacements was found. Some of the boulders illustrated in Pl. XVI have been shifted only an inch or two from the walls which furnished them.

\section{Microscopic Characters of the Pseudotachylyte.}

Sections of most of these rocks must be cut very thin, in order to secure even moderate transparency. The photomicrograms shown were taken by electric light, with exposures up to 2 minutes, yet the base of the rock appears perfectly black, and only the inclusions exhibit detail. The opacity of the base is due to a multitude of minute black specks (of magnetite), which not only stop a great deal of light, but also make it extremely difficult to. determine the nature and properties of the transparent components. of the ground-mass. Examination of a large number of slides, all made by myself, has shown that three types of ground-mass are represented, as described below. The inclusions are alike in all cases, and will be described afterwards.

Type 1.-This is the most opaque type of all, and is found generally in the thinner veins, those less than a couple of inches wide. Clouds of magnetite-grains of irregular shape obscure all detail. Behind these grains one sees a structureless background, which is not perfectly isotropic, but gives dull-grey tints between crossed nicols. The mass is not homogeneous, since. different parts do not extinguish at the same time, but boundaries between the different portions cannot be made out; the appearance is not in the least suggestive of a powder. Some specimens are nearly isotropic, of very dark colour, and show a concentration of the black colouring-matter at many centres. A slight streakiness of the colouring-matter, suggestive of flowstructure, is rarely seen. Fragments of these black rocks, free from visible grains of quartz and felspar, were picked out and placed in bromoform (specific gravity $=2 \cdot 8$ ); they all floated.

Type 2.- In this type a certain amount of crystallization has taken place. The magnetite-grains are in part tiny octahedra, and are accompanied by swarms of grains and scales which are pleochroic from yellowish green to pale grass-green (Pl. XIX, fig. 3). These are so minute and so abundant that in the thicker parts of the slides, as also in the specimens of the finest grain, one has merely an impression of greenness over all. Sometimes the prisms form definite collars or mantles around the xenocrysts. The length of the largest prisms does not exceed 0.08 millimetre, and the average is much less; the breadth is from $0.02 \mathrm{~mm}$. downwards. The extinction of the prisms lies between $10^{\circ}$ and $20^{\circ}$; they have high refraction and low birefringence (firstorder colours), and they show a perfect cleavage parallel to their length. I am not able to distinguish cleavage in cross-sections, but of all the common rock-minerals the characters just enumerated clearly indicate a hornblende. Tiny scales of brownish-green biotite are also present in less abundance. Through the clouds of magnetite, hornblende, and biotite-grains, one sees again a feebly polarizing background which is either indeterminable, as in type 1 , or else passes over towards type 3 .

Type 3.-This type of ground-mass is found in some of the widest veins, but also in some thinner ones, which are not externally different from the 
others. It does not seem to constitute entire veins, but to occur in patches. within rocks which also show type 2 . Considering the invariable blackness. of the rocks, it is surprising to find that the section often shows very little of dark or opaque minerals, but consists either of a honeycomb of polygonal spherulites of a dark-brown colour, showing a perfect cross between crossed nicols (Pl. XIX, fig. 4), or of a felt of felspar-microlites with a subordinate amount of magnetite-dust and a few green scales in the interstices (Pl. XIX, fig. 5). The microlites rise to $0.05 \mathrm{~mm}$. in length and $0.01 \mathrm{in}$ width. They are all twinned, and, although their small size makes the determination difficult, it seems that both Carlsbad and albite twins are present. The extinction is always straight or practically so, and it is probable that both orthoclase and oligoclase are represented. The arrangement of the microlites is generally. radial, not parallel, and it is thought that the stellate groups of microlites. have developed out of spherulites.

The granite-walls and inclusions.-I have cut various. sections across the junction between granite and pseudotachylyte, and $I$ find that in general the granite shows no change which can be traced farther than 1 or $2 \mathrm{~mm}$. from the edge. In some cases. this junction is absolutely sharp, and the granite betrays no change. whatever. Such a junction is shown in Pl. XIX, fig. 1, where a single plagioclase crystal is seen to be cut sharply across, as if by a knife; a few tiny cracks are observed at right angles to the fractured surface, and along these there has been a very slight. faulting of parts of the crystal; but, with this exception, the twinning lamellæ are perfectly straight, showing that there bas been no shearing of the granite parallel to the vein. 'This is not an isolated instance-I have observed the same feature in several slides. The general conclusion as to the absence of shearing in the granite holds rigidly for every case that I have studied in the field or in the laboratory. In one case a crystal of titanite was found, half of which is embedded in the granite-wall, while the other half projects well into the tachylyte-vein; here is proof positive of the absence of shearing.

In other cases the quartz- and felspar-crystals of the granite, within a space of 1 or 2 millimetres from the edge, are considerably cracked, show a very irregular extinction, and are invaded by tongues of pseudotachylyte. Fragments of quartz and felspar actually enclosed in the vein-rock are much cracked, the quartzgrains in particular showing a beautifully minute mosaic structure between crossed nicols. This granulation is unaccompanied by schistosity, and is such as might have been caused by rapid heating of the crystals. PI. XVIII, fig. 2 shows granitic fragments floating in tachylyte just at the margin of a vein. 'The shadowy grains are felspar, the clear white grains are quartz. All the grains show fretted, embayed outlines, and the suggestion of active corrosion by the black base is very strong. Actual proof of melting of felspar is contained in Pl. XVIII, fig. 1 \& Pl. XIX, fig. 2, which are taken from the margin of a large vein. In these photographs the quartzgrains stand out in clear relief from a matrix of half-melted felspar which shows viscous flow-structure.

Sometimes the included felspars are red, and present a compact, 
felsitic appearance. Slices cut through these red felspars show that the whole substance is minutely granulated, and that in part the felspar has been fused and has afterwards crystallized in the form of perfect spherulites.

It is remarkable that only the quartz and felspars of the granite appear among the inclusions; in no single instance is the biotite preserved. In view of the evidence of high temperature shown by the melted felspar, this becomes intelligible: biotite is decomposed by moderate heat, and its decomposition has furnished the abundant magnetite of the base of the rock. Although felspar is more abundant than quartz in the granite, yet among the inclusions quartz is more noticeable than felspar. In one case an inclusion of amphibolite was discovered in one of the veins. The bright-green hornblende shows no granulation, and is quite unchanged save at the very elge of the inclusion, where it loses its well-rleveloped cleavage and takes on a fibrous appearance, although keeping its pleochroism and its uniform extinction. Round about the inclusion the psendotachylyte is coloured green, hence solution is again indicated.

The only other xenocrysts that I have observed are a few unchanged crystals of zircon, sphene, and magnetite. The pseudotachylyte is always perfectly fresh, and no hyclrous secondary minerals have been observed in any case.

\section{V. The Case for the laxeols Oragin of the Vems.}

The evidence which suggests an igneous origin for these veins, and led to their being regarded as talchylytes in the first instance, may now be summarized :-

(1) The mode of oceurrence in the field, as described above which is quite consintent with an igneoum intrusive origin, but difficult to reconcile with any other known manner of formation.

(2) The abrupt contacts between vein-rock and granite, and the absence of shearing in the granite.

(3) The common occurrence of blind intrusions.

(4) The presence of rounded boulders and fragments in the veins, as also the microscopic evidence of corrosion and even fusion of these and of selective destruction of the constituents in a definite order.

(5) The presence of spherulitic and microlitic structures that find their nearest analogues in vitreous dyke-rocks and lavas in which crystallization has taken place subsequent to consolidation as glass.

(6) The sharp distinction which exists between the inclusions and the matrix.

(7) Although unquestionable igneous intrusions are not often seen in the granite, yet there is at least one basic dyke of the largest size in the very heart of the area, thus demonstrating the presence of basic magma in depth. This is a dyke of granophyric quartz-dolerite, nearly 600 yards wide, which is exposed in a shallow valley at the weir, above Parijs. Mr. J. W. Penny has described basic intrusions in the Lower Witwatersrand Beds which overlie the granite. 


\section{Comparison of the Psevdotachicte with 'Trap- Shotten Greiss' and ' Fuintr Chush-Rock.'}

The term trap-shotten (that is, trap-injected) gneiss was. employed by W. King \& R. B. Foote for parts of the gneiss of Salem (Madras), which they describe as being "very largely impregnated or shot with strings of dark green or bluish-black compact trap.' 'The supposed trap-veins of this area were subsequently studied by Sir Thomas Holland, who found them to consist of an indurated black dust, through which fragments of quartz and felspar are disseminated. He was able to imitate the material by heating powdered gneiss to white heat in a furnace, and he concluded that the production of the veins was due to the brecciation of the gneiss along certain lines, but not to injection of trap; the black colour and indurated nature of the material he ascribed to the action of heat produced during the violent brecciation of the rock.

The manner in which these dark veins occur in the field, as. described and illustrated by the above-mentioned writers, recalls. many of the features of the Parijs occurrence. Important points of difference, however, are that the so-called 'trap-shotten' bands occur in roughly parallel belts which coincide with lines of dislocation, and that they are often associated with true igneous intrusions of a basic nature. With regard to microscopic characters, the difference is fundamental; in no single instance that $I$ have observed can the matrix of the Parijs rocks be described as a 'black dust' or powder.

In Scotland rocks of somewhat similar characters to the above have been described as 'Hinty crush-rocks' and mylonites. Many references to such rocks occur in the Geological Survey Memoir on the North-West Highlands, and attention may be drawn especially to the descriptions on pp. 124, 221, and 249 . It is again significant that the veins are found only in highly dislocated regions-especially along, or in the neighbourhood of, well-marked fault-planes and zones of crushing. In most cases the flinty material is associated with bands of a more clearly granulitic or mylonitic character, and it has been suggested that by the intensity of the crushing sufficient heat may have been generated to fuse sinall portions of the rock. Some of the specimens in the Geological Survey collection show the occurrence of black flinty material as streaks within ordinary mylonite, apparently confirming the above view; a good example of this is Slide 12933 .

Dr. Harker has described crush-lines in granite near Broadford (Skye), and notes that the most marked effects are restricted to the vicinity of faulted boundaries. The flinty crush-rocks of the Cheviot Hills, discovered by the late Dr. C. 'T. Clough, also occur along crush-lines in granite. Sections of these rocks, which Dr. Clough kindly permitted me to examine, show the clearest. evidence of shearing; but they range from obvious mylonites, 
consisting of angular fragments of quartz and felspar, to very dense, structureless, black bands the origin of which might have remained obscure if they had not been associated with coarser granulitic material. Dr. Clough informed me that these veins were at one time considered to be of igneous origin; in my view, however, their true nature is unquestionably clearer than that of the Parijs rocks. The specimens that exhibited the nearest approach to the characters of the pseudotachylyte of Parijs came from Cunyan Crag (Cheviots). Dr. Clough also showed me a flinty erush-rock from South Ben Lee, North Uist (Hebrides), which, in regard to the extreme opacity of its base, almost defying microscopic resolution, resembled the densest examples of my Parijs type 1.

Dr. Clough, Mr. Maufe, \& Mr. Bailey discuss flinty crush-rocks at some length in their paper on the cauldron subsidence of Glen Coe, and give a convenient summary of some of the literature mentioned above. They show that at Glen Coe dark, apparently tachylytic, rocks have been produced by the shearing of various types of rock, quite independently of igneous action. Of especial interest is their observation that in some cases 'the flinty crush-rock las been injected as a fluid away from its source of origin.' By the courtesy of Dr. Flett and the late Dr. Clough and Mr. Bailey, I was enabled to study a large number of hand-specimens and sections from this area, as well as from other parts of scotland. I found that the majority of them were ummistakable mylonites, or eyed gneisses on a microscopic scale; but there seemed to be a representative of every stage between these and a type with almost umresolvable dense base, which may show flow-structure or may lack every trace of orientation. Only the most extreme examples of the latter type are comparable to the Parijs rocks, and none of them showed anything similar to the crystallization of felspar and hornblende-seen at Parijs. The points in which these rocks begin to resemble those of Parijs are the following :-

(1) The base of the rock is sometimes structureless and opaque, and full of tiny black grains, which are in part euhedral crystals of magnetite.

(2) Larger fragments are sometimes rounded, and have what look like reaction-rims, or their margins may appear to have been corroded. Internally they may exhibit a mosaic structure.

(3) In rare cases there are beginnings of crystallization in parts of the base, and in one instance (Meall Riabhach, Ross-shire) typical trichites are developed.

Out of all the material that I examined I was able to select only four specimens of which I could fairly say that they showed a close approach to my Parijs rocks of the first type. ${ }^{1}$

Typical flinty crush-rocks are developed on a very large scale in the province of Olavarria (Argentine Republic), where they have

1 The sections in the Geological Survey collection bear the numbers 12332, 13402, 13403, 12934, 4281. 
been studied by $\mathrm{H}$. Backlund. In his memoir on the subject, Backlund traces the mechanical alteration of a coarse porphyritic granite into a black horny rock with relics of felspar-phenocrysts. Optical deformation of the brecciated fragments is said to be visible in every preparation, and as there is no obvious recrystallization it is concluded that the breccia has not been submitted to any very high temperature. Backlund compares these rocks with Scottish flinty crush-rocks, which they appear to resemble closely. Four chemical analyses are tabulated, two of different facies of the granite-gneiss and two of mylonites. The analyses of mylonite do not differ more from the analyses of granite than do the latter one from the other, and, in particular, the analysis of a 'dense black mylonite with red spots of microcline' corresponds almost exactly to the mean of the two analyses of granite-gneiss.

The only other part of the world from which I have been able to obtain useful information regarding crush-rocks and pseudotachylytes is Little Namaqualand, the north-western corner of the Cape Province. I am indebted to Dr. A. W. Rogers for the following note on the subject:-

'The trap-shotten rocks in Van Rhyn's Dorp and Namaqualand are massive gneiss and occasionally the mica-diorites of the copper-bearing intrusions. The cracks are rarely half an inch wide, usually less than a tenth of an inch. They-or, rather, the instances observed--are in groups several feet long, and the individual cracks give off branches and join up with their neighbours. Though they have no constant direction, the cracks in any one group are parallel in a rough way, and at Jubilee Kop and on Mining Lease 81 they cross the foliation of the gneiss approximately at right angles. The strings are black.'

In sections of one of these black veins from Flamink Vlakte (Namaqualand) I was able to determine the following characters. Under a low magnification the appearance seen is that of a powder consisting of sharp angular grains of quartz and felspar of all sizes, with a sort of cement of green scales. Even the highest magnification fails to reveal anything of the nature of a glassy, spherulitic, or microlitic base. The quartz and felspar fragments are mostly free from cracks, and give a perfectly uniform extinction, while the plagioclases show normal twinning lamellæ. The green scaly substance lying between the colourless grains is made up of shapeless scales of biotite, with perhaps a few scraps of hornblende of the same colour. 'This biotite seems to be mainly detrital, just as the quartz and felspar are, but some of it may conceivably have crystallized in place. 'There is absolutely no suggestion of corrosion, melting, or recrystallization of the quartz or felspar, and nothing whatever to indicate that the temperature was high. Magnetite, which renders the Parijs rocks so dark and opaque, is nearly absent. A few grains of zircon are visible, some of them being enclosed in the larger biotite-scales.

As an illustration of this mylonitic type of crush-rock, which appears to be the standard type in all the regions above described, 
except l'arijs, I include a photomicrograph of the rock of Flamink Vlakte in Pl. XIX, fig. 6. The essential difference between pseudotachylyte and flinty crush-rock is impressively shown when this photograph is compared with Pl. XVIII, fig. 2.

The facts that have been established so far may conveniently be tabulated in the following form:-

(a) Black rocks are composed of crushed material without recrystallization or any evidence of elevated temperature: Argentine; Namaqualund; most Scottish and Indian localities.

(b) Black rocks are composed of crushed material, but with evidence of high temperature approaching the melting-points of some of the constituents, and with beginnings of crystallization : some Scottish localities, especially Glen Coe, Meall Riabhach, and North Uist; some Indiun localities (P).

(c) Black rocks hold inclusions of fragmental material, but lack proof of origin by crushing; the temperature exceeded the melting-point of felspar, and spherulitic and microlitic crystallization took place : Parijs.

Regarding the evidence from a purely qualitative standpoint, it would seem that we have a complete series of rocks comnecting up the pseudotachylyte of Parijs with ordinary mylonite, the various links in the series being as follows :-

mylonite $\rightarrow$ fritted mylonite or flinty crush-rock $\rightarrow$ fused mylonite or psendotachylyte (type 1$) \rightarrow$ recrystallized pseudotachylyte (types 2 \& 3).

Arguing on these lines, it is possible to maintain the view that pseudotachylyte is simply an extreme form of flinty crush-rock, the production of which involved a greater generation of heat than usual.

Against this view of the origin of pseudotachylyte there are some very weighty arguments. The supposed series of rocks connecting pseudotachylyte with mylonite, although qualitatively complete, is very imperfect when examined quantitatively. In all the regions that have been mentioned here, except Parijs, the first member of the supposed series is abundant, the second member much scarcer, the third member is limited to a few minute or even microscopic occurrences, while the fourth member does not occur. At Parijs, on the other hand, the first and second members are entirely absent (at least a close search has failed to reveal them), while the third and fourth members occur in great abundance throughout a large area. These considerations cast the gravest doubt upon the actual continuity of the supposed series. In fact, the only conclusion that the study of flinty crush-rocks entitles us to draw is that products similar to pseudotachylyte can be, and in rare cases have been, produced by crushing and heating associated with movement along planes of dislocation.

Further objections to the comparison of pseudotachylyte with flinty crush-rock are as follows :-- 
(1) The absence of shearing and cataclastic phenomena in the granite. This can only be accounted for by supposing the fractures to have been produced by sudden snapping of the granite in response to a sudden stress; but how, unless there was long-continued friction, could the quantity of fine dust necessary to fill the fissures be supplied?

(2) The common occurrence of blind veins seems positively to exclude the possibility of long-continued friction; the blind veins do not differ in texture or composition from the others.

\section{The Chemicat Composition of the Pseudotachroy'se.}

(See also Appendix, p. 217.)

When I first examined these rocks, I had no means of making a chemical analysis of the material. Subsequently, when the question of the origin of the pseudotachylyte was reopened, my assistant, Mr. R. A. Page, kindly undertook to perform the necessary analyses, and the figures given below are due to him. In justice to Mr. Page, I must state that the work was performed under very unfavourable conditions, with a deficient supply of platinum vessels, with acetylene burners and a spirit blast-lamp for ignition, and without reagents of special purity ; consequently, it was not expected that a high degree of accuracy could be attained. The summation of the analyses is low ; but, as we are concerned rather with the general chemical character of the rock than with the very precise determination of individual constituents, the result has proved quite serviceable, and I desire to record my great indebtedness to Mr. Page for his careful labour. The figures are given in the first two columns below; those in the third and fourth columns refer to Backlund's analyses of black mylonite and grey mylonite respectively, the minor constituents being omitted :-

\begin{tabular}{|c|c|c|c|c|}
\hline & I a. & I $b$. & II. & III. \\
\hline 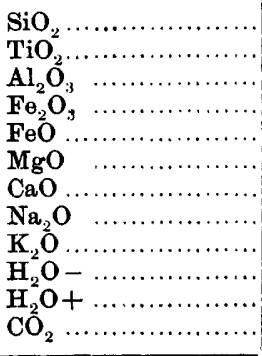 & $\begin{array}{r}62 \cdot 03 \\
\text { n. d. } \\
16 \cdot 57 \\
2 \cdot 51 \\
2 \cdot 90 \\
0 \cdot 39 \\
3 \cdot 39 \\
6 \cdot 37 \\
3 \cdot 41 \\
0 \cdot 16 \\
0 \cdot 72 \\
0 \cdot 00\end{array}$ & $\begin{array}{c}62 \cdot 66 \\
\text { n. d. } \\
16 \cdot 26 \\
2 \cdot 51 \\
2 \cdot 89 \\
\text { n. d. } \\
3 \cdot 99 \\
5 \cdot 88 \\
2 \cdot 75 \\
0 \cdot 96 \\
\ldots\end{array}$ & $\begin{array}{r}65.75 \\
0.66 \\
15.56 \\
0.64 \\
3.30 \\
1.77 \\
3.75 \\
3.11 \\
4.11 \\
0.08 \\
0.69 \\
0.74\end{array}$ & $\begin{array}{r}68 \cdot 24 \\
0 \cdot 01 \\
16 \cdot 08 \\
0 \cdot 81 \\
2 \cdot 20 \\
0 \cdot 40 \\
3 \cdot 42 \\
3 \cdot 34 \\
3 \cdot 99 \\
0 \cdot 08 \\
0 \cdot 83 \\
0 \cdot 59\end{array}$ \\
\hline Totals & $98 \cdot 45$ & $97 \cdot 90$ & & \\
\hline
\end{tabular}

$\mathrm{TiO}_{2}, \mathrm{ZrO}_{2}, \mathrm{MnO}$, and $\mathrm{P}_{2} \mathrm{O}_{5}$ were present in small quantities, but were not determined by Mr. Page.

Q. J. G. S. No, 287. 
The rock chosen for analysis shows a combination of the characters of types $2 \& 3$ as above described-that is, it contains both felspar-laths and hornblende-prisms, with magnetite. The average diameter of grain is 0.01 millimetre, and the usual quartz- and felspar-inclusions are present in comparatively small amount in the hand-specimen, although well-rounded inclusions are very numerous uncler the microscope. An apparent discrepancy exists between the abundance of hornblende in the ground-mass of the rock and the rather low figure for magnesia in the analysis; but it is possible that the place of magnesia is largely taken by furrous oxide, and that the amphibole is rich in the griünerite molecule.

The norm of this rock, as calculated from the first analysis, is as follows:- Quartz 9.72, orthoclase $37 \cdot 81$, albite $28 \cdot 82$. anorthite $11 \cdot 12$, diopside $5 \cdot 02$, hypersthene $1 \cdot 49$, magnetite $3 \cdot 71$. The rock, therefore, falls into persalane, subrang pulaskose $(\mathbf{I}, 5,2,3)$.

Conclusions to be drawn from the analyses.-It was recognized from the beginning that a chemical analysis would probably prove inconclusive as regards the origin of the veins, because $(a)$ it is not possible to separate the ground-mass of the rock from the minute granitic inclusions which occur all through it, and (b) whatever theory of the origin of the veins one may favour, it is certain that some part of the granite-especially the biotite, but also some of the felspar-has already been incorporated in the ground-mass. The analysis, therefore, gives the composition of the ground-mass plus that of inmumerable quartzand felspar-inclusions.

No analysis has been made of the granite-gneiss in which the veins occur: this is a composite banded gneiss in which different bands show a very wide range of composition, and no single analysis could give a fair idea of the average composition. From the mineralogical examination of the various facies of the gneiss, however, one may describe the rock-complex as a whole as having the composition of a granorliorite. The real utility of the above analyses, therefore, lies in showing that the composition of the pseudotachylyte is such as might result from the commingling of fragments derived from the different leucocratic and melanocratic bands of the gneiss.

My original assumption, that the dykes consist of basic igneous material (approximately of the composition of basalt) which has acidified itself by solution of granite, is now seen to be scarcely tenable. The figures for alkalies and magnesia, in particular, are such as no mixture of granite and basalt could give. Again, in order to account for the proportion of silica alone, it would be necessary to assume that our hypothetical basaltic magma took up in solution and suspension from one and a half to three times its own weight of granite, since, according to Dr. Daly's figures, the average silica of basalts is 49 per cent. and that of granodiorites and granites from 65 to 69 per cent. The actual proportion of suspended granite-fragments (that is, inclusions) in the analysed 
rock was determined by geometrical measurement of four thin sections; the results were $25 \cdot 3,26 \cdot 4,28 \cdot 2$, and 43.5 per cent. respectively, giving an average of about 30 per cent. Hence, in order to account for the observed composition of the pseudotachylyte, we should be driven to the assumption that the supposed basaltic ground-mass had actually dissolved and completely assimilated about its own weight of granite. But a simple calculation based on the known values of the specific heat and latent heat of fusion of the common silicate-minerals shows that a magma, to dissolve its own weight of foreign rock, would need to have an initial temperature enormously in excess of any temperature known to be realized in the higher zones of the lithosphere.

If, then, the participation of an igneous magma is to be assumed at all, it must be a magma considerably richer in silica and alkalies than basalt. But here we are faced by the fact that the only body of magma that is known to underlie the granite-gneiss in this region is the body which gave rise to the enormous dolerite-dyke at the weir above Parijs, and to the various 'diabases' in the Lower Witwatersiand rocks. The analysis, therefore, deprives the igneous theory in its original form of an important buttress. If we try to modify that theory by assuming that the invading magma was of andesitic or dacitic composition, we merely beg the question.

\section{The Case against an Igneods Origin.}

So long as no other than an igneous origin suggested itself, certain peculiarities of structure and composition exhibited by the pseudotachylyte could be overlooked; but, with an alternative solution in the field, these points of singularity must be regarded as evidence against the igneous theory. 'The main points militating against the acceptance of the igneous theory are as follows :-

(1) The total absence of macrocrystalline equivalents of the pseudotachylyte.

(2) The total absence of differentiation between the central and the marginal portions of the veins.

(3) The general absence of flow-structure.

(4) The extreme opacity of the most glassy-looking rocks, and the abundance of powdery magnetite in them.

(5) The absence of perfect isotropism, even in the most structureless types.

(6) The low water-content of the rocks. Mr. R. A. Page determined for me the total loss on ignition in the case of one of the most nearly glassy rocks (type 1); it amounted only to 0.83 per cent., which is much lower than the average figure for pitchstones.

(7) The melting (as distinct from dissolution) of felspar contacts. This is a phenomenon for which I can recollect no parallel among igneous rocks ; it seems to demand a temperature higher than one can concede to a thin tongue of magma far from its source.

(8) The analogy between these rocks and the rare semi-vitrified crushrocks of Scotland, and through these with other Scottish occurrences of flinty crush-rocks and with the mylonites of Argentina, India, and Namaqualand. 


\section{Conclusion.}

There are two explanations before us of the origin of these pseudotachylytes: one is, that they represent end-products of the same process as that by which thinty crush-rocks have been produced; the other, that they are true igneous intrusions. I have stated the evidence for and against both hypotheses without prejudice. I must now add that the result of my study of flinty crush-rocks has been to make me chary of reasserting the normal igneous origin of the pseudotachylyte. 'The only point as to which $I$ am really satisfied is the intrusive relation of the material to its walls. Before rejecting the igneous theory, however, on account of the evidence which has already been cited against it, we may pause to consider whether a melt of granite, produced within the granite itself by mechanically-developed heat, would not differ in its properties from a normal granitic magma owing to the absence of the usual volatile constituents of a magma. Such a melt, being in all probability extremely viscous, might be unable to undergo differentiation or to crystallize as a magma would; hence the absence of differentiation and of planerocrystalline products, although hardly compatible with consolidation from a magma, is, perhaps, not incompatible with consolidation from a rock-melt. That the pseudotachylyte is the product of such a rock-melt, as distinct from a magma, is the hypothesis that best explains the facts. It depends, however, on the assumption that the heat necessary to fuse the granite on the large scale which the intrusions indicate is capable of being produced by the sudden rupture of the granite without long-continued friction or shearing. The validity of this assumption, as well as the properties of such a rock-melt under high pressure, can only be guessed at. Granted the necessary postulates, then this hypothesis adequately explains the phenomena.

Should the above assumption not prove aceeptable, there is still one possibility left. Prof. Stanislas Meunier and other's still believe in the causation of earthquakes by deep-seated explosions. The conditions at Parijs are not such as Prof. Meunier postulates, but there is abundant evidence that the sub-crust of these parts of South Africa has in the past contained highly explosive material : witness the hundreds of tuff-filled pipes which have been drilled through the crust in the Orange Free State, the Transvaal, and the adjacent parts of the Cape Province. The extrusion of the great dolerite-dyke at Parijs itself demands an expulsive force of enormous power. The form of the pseudotachylyte veins indicates that the granite was shattered by a sudden gigantic impulse or series of impulses. If this impulse were of the nature of an explosion in the sub-crust, it would have as a necessary consequence the outrush of incandescent gases through all the fissures of the granite. In these circumstances fusion of the walls of the fissures might well ensue. Sir Andrew Noble's experiment, in which cordite was exploded in steel cylinders and the gases allowed 
to escape through a small hole in a granite stopper, will at once recur to the memory. Here is not only a possible source of the vein-material, but an explanation of the high temperature to the action of which that material testities. I hardly dare offer this as a serious hypothesis, since it takes us away from known causes altogether; but, when one is dealing with an extraordinary phenomenon, no possibility is too extraordinary to be worthy of consideration.

In brief, the material of the pseudotachylyte seems to be melted granite-this is indicated by the chemical characters, and is consistent with the microscopical evidence; it behaves towards the granite like an igneous intrusion-this is established by the field-observations. The source of the heat and the mechanics of the intrusive process remain obscure.

\section{Literature.}

F. H. HAтCH.-- 'A Geological Map of the Transvaal ' in Hatch \& Corstorphine's 'Geology of South Africa' 2nd ed. 1909.

G. A. F. MolengraAfF.- ' Remarks on the Vredefort Mountain-Land' Trans. Geol. Soc. S. Africa, vol. vi (1903) pp. 20-26.

F. W. PennY:- The Relationship of the Vredefort Granite to the Witwatersrand System' Q. J. G. S. vol. lxx (1914) pp. 328-34.

W. KING \& R. B. Foote.- On the Geological Structure of the Districts of Trichinopoly, Salem, \&c.' Mem. Geol. Surv. India, vol.iv (1864) pp. 223-377.

T H. Holland.- - The Charnockite Series' Mem. Geol. Surv. India, vol. xxviii (1900).

B. N. PeAch \& others.-- The Geological Structure of the North-West Highlands of Scotland' Mem. Geol. Surv. 1907.

A. HARKER.- - The Tertiary Igneous Rocks of Skye' Mem. Geol. Surv. 1904, p. 167.

C. T. Clovgh, H. B. Maufe, \& E. B. Batley.- 'The Cauldron Subsidence of Glen Coe' Q. J. G. S. vol. lxv (1909) pp. 611-76.

H. BACKLUND.- 'Algunas Observaciones sobre Rocas Notables provenientes de Olavarriá ' Dirección General de Minas, Boletin No. 2, Buenos Aires, 1913.

\section{Appendix [September 1916].}

\section{Some fresh Analyses of the Granite and Pseudotachylyte of Parijs, made by Dr. H. F. Harwood.}

Through the kind mediation of Dr. Arthur Holmes, Dr. H. F. Harwood, of the Imperial College of Science \& Technology, has lately been induced to undertake the analysis of the granite and pseudotachylyte, in order to settle the question of the origin of the latter. For this purpose I supplied him with :-

(1) the residue of the material already analysed by Mr. R. A. Page and described by me in the foregoing pages, and

(2) a large block from the locality shown in Pl. XVII, fig. 1, consisting of part of the tachylyte vein $(2 a)$ and part of the granite wall $(2 b)$. 
The analytical results are tabulated below under these numbers:-

\begin{tabular}{|c|c|c|c|}
\hline & (1) & $(2 a)$ & $(2 b)$ \\
\hline 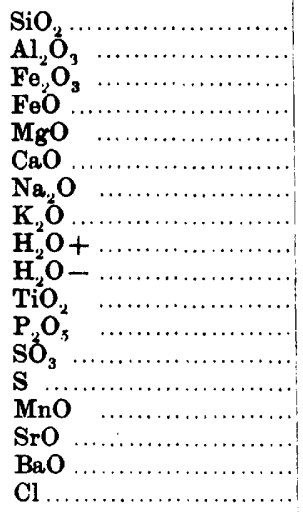 & $\begin{array}{r}64 \cdot 87 \\
15 \cdot 62 \\
1 \cdot 90 \\
2 \cdot 50 \\
1 \cdot 77 \\
3 \cdot 73 \\
4 \cdot 29 \\
2 \cdot 92 \\
0 \cdot 57 \\
0 \cdot 08 \\
1 \cdot 32 \\
0 \cdot 27 \\
\text { none } \\
0 \cdot 06 \\
0 \cdot 05 \\
\text { trace } \\
0 \cdot 01 \\
\text { trace }\end{array}$ & $\begin{array}{r}66 \cdot 95 \\
15 \cdot 06 \\
1.58 \\
2 \cdot 18 \\
1.38 \\
3 \cdot 25 \\
4.32 \\
2 \cdot 85 \\
0 \cdot 51 \\
0 \cdot 12 \\
1 \cdot 75 \\
0.07 \\
\text { none } \\
0 \cdot 12 \\
0 \cdot 03 \\
\text { none } \\
0 \cdot 05 \\
\text { trace }\end{array}$ & $\begin{array}{r}67 \cdot 72 \\
15 \cdot 79 \\
1 \cdot 04 \\
2 \cdot 33 \\
0 \cdot 99 \\
2 \cdot 93 \\
4 \cdot 49 \\
2 \cdot 21 \\
0 \cdot 68 \\
0 \cdot 11 \\
1 \cdot 36 \\
0 \cdot 11 \\
\text { none } \\
0 \cdot 02 \\
0 \cdot 02 \\
0 \cdot 03 \\
0 \cdot 01 \\
\text { trace }\end{array}$ \\
\hline \multirow[t]{2}{*}{$\begin{array}{l}\text { Totals ............... } \\
\text { Less } 0 \ldots \ldots \ldots \ldots \ldots\end{array}$} & $\begin{array}{r}99 \cdot 96 \\
0 \cdot 02\end{array}$ & $\begin{array}{r}100 \cdot 22 \\
0.05\end{array}$ & $99 \cdot 84$ \\
\hline & $99 \cdot 94$ & $100 \cdot 17$ & \\
\hline
\end{tabular}

The analysed specimen of the granite-gneiss is distinctly banded in hand-specimen, the individual bands of alternately light and dark colour being 1 to $2 \mathrm{~mm}$. thick and neither regular nor persistent when examined minutely, yet sufficiently so to give a distinct grain to the rock. Both white and flesh-red felspars are seen, the latter being the larger and tending to produce eyes. Both orthoclase and oligoclase are present, with biotite as the only dark silicate. Grains of apatite are rather abundant, with some ilmenite and titanite, and large irregular patches of quartz make up about a quarter of the rock. The chemical and microscopical characters determine the rock to be essentially a granodiorite; but, as I have already expressed the opinion that the whole mass is a hybrid granite-gneiss the composition of which varies greatly from place to place, there is no need to lay stress on the name.

The analysed specimens of pseudotachylyte are of my type 2, passing towards 3-that is to say, they contain abundant hornblende-needles and magnetite-grains; but in places, and especially round the larger inclusions, felspar-laths are also prominently developed.

Comparing the figures for the two kinds of rock, it is evident that they are so nearly identical as positively to exclude the participation of a foreign magma in the production of the pseudotachylyte. The greater content of potash, magnesia, and iron in the pseudotachylyte, as compared with the granite, doubtless arises 
from the fact that biotite is the first mineral to fuse. In preparing the powder of $2 a$ for analysis, the larger fragments of quartz and felspar were probably rejected (at least, that was my own procedure); but no biotite was rejected with them, hence the enrichment of the base in the constituents of biotite.

All three analyses fall, in the quantitative classification, into lassenose $(\mathrm{I}, 4,2,4)$-a group containing many plagioclase-granites and dacites.

The conclusion to which my re-examination of the rocks, coupled with Mr. Page's analysis, had already led me is, therefore, completely confirmed by Dr. Harwood's work. The pseudotachylyte has originated from the granite itself through melting, caused (as I bave shown) not by shearing but by shock, or, alternatively, by gas-fluxing.

I wish to offer my warmest thanks to Dr. Harwood for his kindness in performing the above analyses, and thus enabling the investigation of these remarkable rocks to be completed; and also to Dr. Holmes for so kindly interesting himself in the matter.

\section{EXPLANATION OF PLATES XVI-XIX.}

\section{Plate XVI.}

A large vein of pseudotachylyte exposed in a cutting made for one of the piers of the new bridge below Parijs (Orange Free State).

\section{Plate XVII.}

Fig. 1. A vein coming up vertically, turning over to a nearly horizontal plane, and thinning out. Thickness of the vein = about 6 inches in the middle of the photograph. Exposed in a cutting at the bridge. (The detail of the blind end of this vein is shown in text-figure 8 , p. 203.)

2. $\mathbf{A}$ boulder from one of the large veins, thrown out during blasting operations at the weir, above Parijs: shows rounded floaters of granite and gneiss. A foot-rule has been placed alongside, in order to give the scale.

\section{Plate XVIII.}

Fig. 1. Melted felspar at the margin of a vein. The clear white areas are quartz-grains. $\times 15$ diameters. (See p. 207.)

2. Section near the margin of a vein : it shows granite fragments being detached, apparently corroded, and floated away. $\times 15$ diameters. (See p. 207.)

\section{Plate XIX.}

Fig. 1. Margin of a vein, showing a plagioclase-crystal which has been broken but not sheared. Crossed nicols. $\times 15$ diameters. (See p. 207.)

2. Melted felspar at the margin of a vein. The clear colourless areas are quartz-grains. $\times 15$ diameters. (See p. 207.)

3. Pseudotachylyte with ground-mass of type 2 , full of minute hornblendeprisms. $\dot{x} 45$ diameters. (See p. 206.) 
Fig. 4. Spherulitic ground-mass, type $3 . \times 80$ diameters. Crossed nicols. (See p. 206.)

5. Ground-mass of felspar-microlites, type $3 . \times 100$ diameters. Crossed nicols. (See p. 206.)

6. Flinty crush-rock from Flamink Vlakte (Namaqualand). $\times 15$ diameters. (See p. 211.)

\section{Disciession.}

Sir J ETURO 'TEALI considered that the paper was an important contribution to a most interesting and difficult subject. 'The facts had been very clearly described by the Author. He (the speaker) had examined many specimens of "flinty crush' from Scotland, and had been much puzzled to aceount for the phenomena. The bits of quartz and felspar which often formed a large part of the rock showed marked signs of crush and stmin, while the dark matrix rarely exhibited any signs of errstallization. The flinty material occurred in thin veins which sometimes anastomosed. He found it very difficult to underst:mol how the material was produced, and how it came to be distributed in this way through the rock from which it was largely if not entirely produced.

Mr. J. F. N. Grees said that, whatever might be the case with the occurrences which had been quoted from India and other places outside South Africa, there did not appear to be any evidence for crushing in the description that had just been given. Except for the character of the country-rock, the macroscopic phenomena were of a kind familiar to students of the volcanic areas of this country. He placed on the table two specimens from the Lake District showing, on a small scale, brecciation, comminution, blind veins, etc., closely resembling the photographs and drawings exhibited.

Mr. E. Greensy drew attention to some specimens and slides of 'flinty crush-rock' from the Lewisian Aneiss of Scotland that were exhibited on the table, and had been kindly lent by the Geological Survey. When he first met with these veins in the Loch Maree country, five-and-twenty years ago, he certainly supposed that they could be nothing but igneous injections. Soon afterwards, however, on the other side of the lake, he found that the same kind of material, appearing first as veins in almost uninjured gneiss, increased rapidly in quantity towards a powerful zone of crush near the lake-side, until, in that zone, the gneiss was permeated by it in all directions. The dynamic origin of the material (already advocated by Dr. Clough) was here unquestionable. One of the slides on the table showed microlithic structure in a vein-rock, another showed crushed gneiss of the lake-side zone breaking down and passing into 'flinty' matter.

Dr. A. Holmes said that, having now heard the revised version of the Author's paper, he was still inclined to support the original suggestion that the pseudotachylyte veins were of igneous origin. The form of the intrusion could be paralleled in Mozambique, where the speaker had seen irregular veins of granulitic granite penetrating gneiss in an equally intricate fashion. If the pseudotachylyte were the result of crushing in situ, then every gradation 
between fused material and mylonite ought to be represented. There did not appear to be such a gradation; while, on the other hand, there was abundant evidence that the material had possessed a sufficiently high temperature to fuse the minerals of the invaded rocks. The question then arose: why had the black rock crystallized so badly? One explanation might lie in the assumption that the intrusion was feebly supplied with volatile fluxes; and such a condition would naturally arise if some deep-seated rock that had previously crystallized and lost its fluxes, were again to be raised to its melting-point-by severe crushing, or rise of the geotherms, or any other cause.

The Author stated, in the abstract of his paper, that the composition of the rock was practically that of a granodiorite, and that it might correspond to an average of the granite-types in which the veins occurred. The speaker said that he could not agree with either of these statements, for the analysis showed about 10 per cent. of alkalies, with soda nearly twice as abundant as potash. The speaker suggested that, if the Author could have specimens of the pseudotachylyte and of the red and grey granites sent to England for analysis, the results could not fail to throw more light on the origin of this most puzzling of rocks.

Dr. J. W. Evars thought that it was clear, in the majority of cases, that the material of pseudotachylyte had been injected into the rock in a fluid or pasty condition, as the result of pressure at right angles to the general direction of injection. It did not appear to be derived from an extraneous magma, but at least in some cases, including that described by the Author, the matrix had been in a molten state. It was doubtful whether the heat produced by earth-movements was ever sufficient to cause an appreciable rise in temperature, and the speaker was inclined to attribute the melting to a regional rise in temperature which did not melt the granite because this had lost its magmatic water. The intrusive material may have been formed from a basic segregation, more easily fusible on account of the larger proportion of iron and alkalies. Such segregations would in many cases determine planes of weakness in the rock. The brecciation of the granitic material included in the veins might, in some cases, be attributed to the forcible injection of the latter. 
Downloaded from http://jgslegacy.lyellcollection.org/ at National University of Singapore on June 12, 2014 . SOC. Vol. LXXII, PL.XVI.

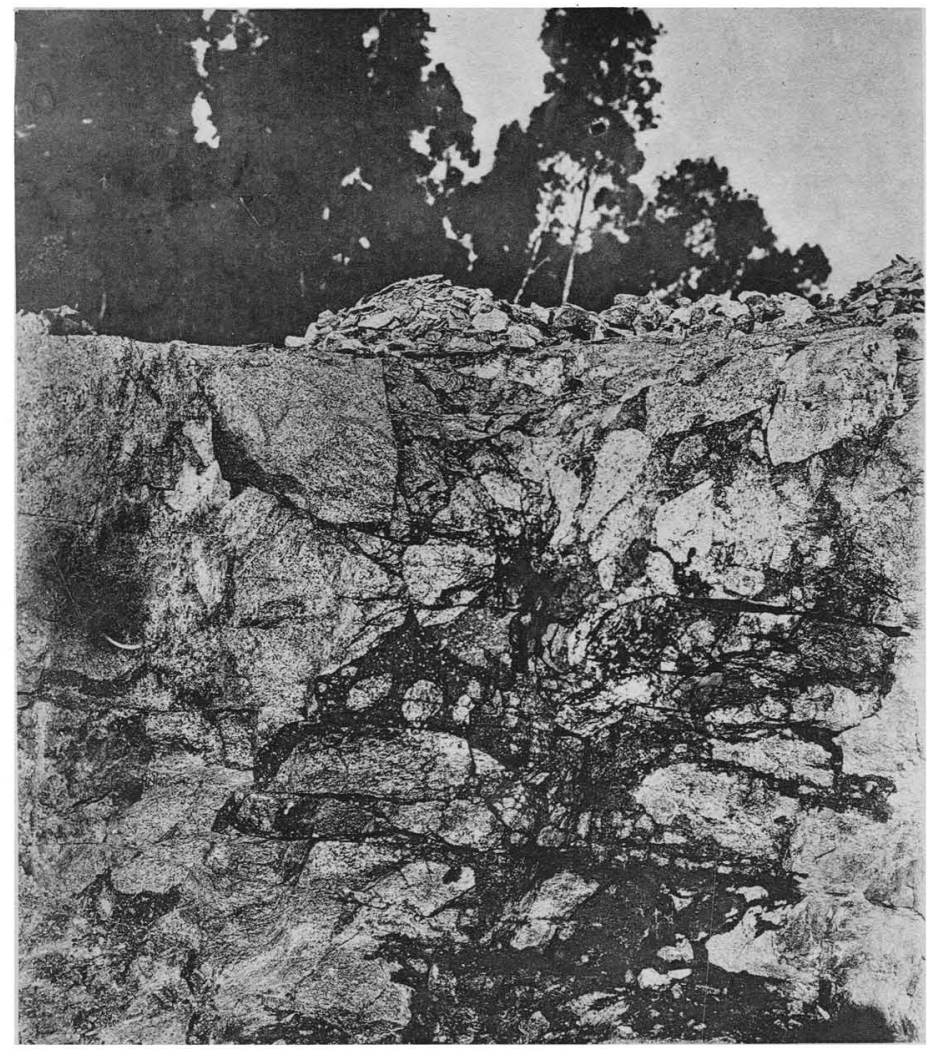
BELOW PARIJS (O.F.S.). 


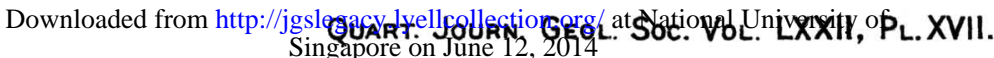

Fig. I. Vein of Pseudotachylyte near Parius (O. F. S.).

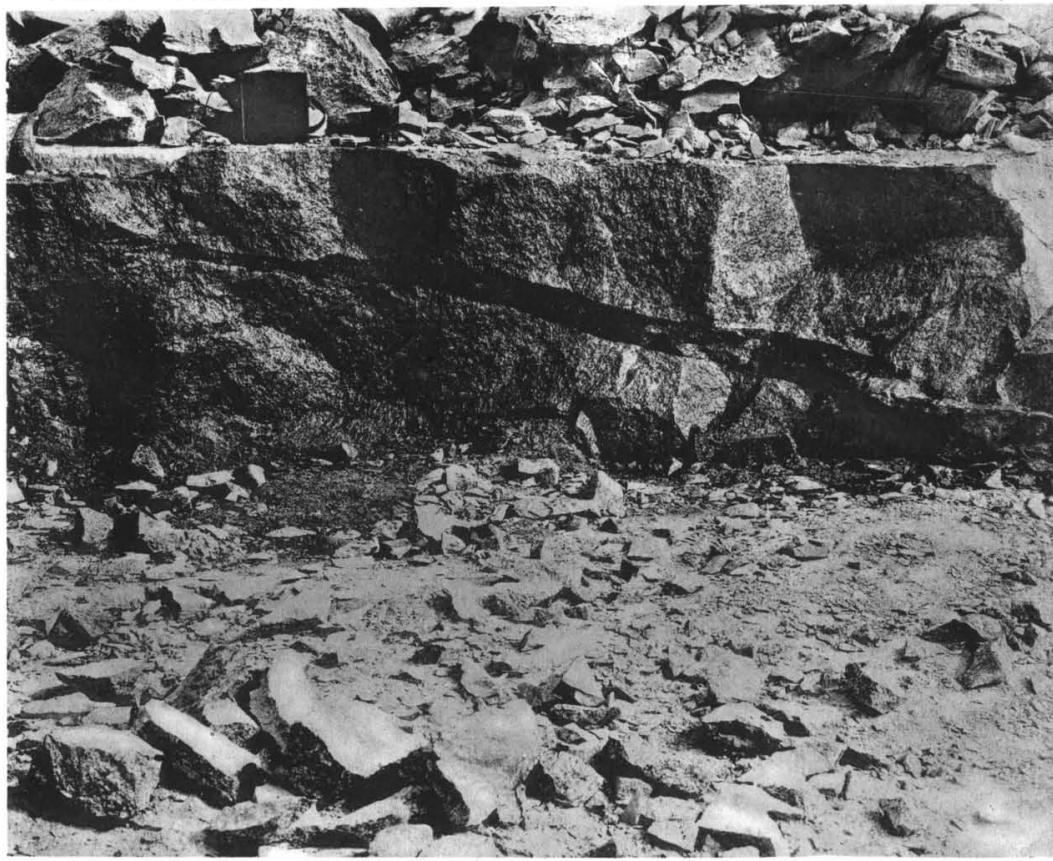

\section{S.J. S., Photo.}

Fig. 2. A Boulder from one of the large Veins OF PSEUdotachylyte near PaRIJs.

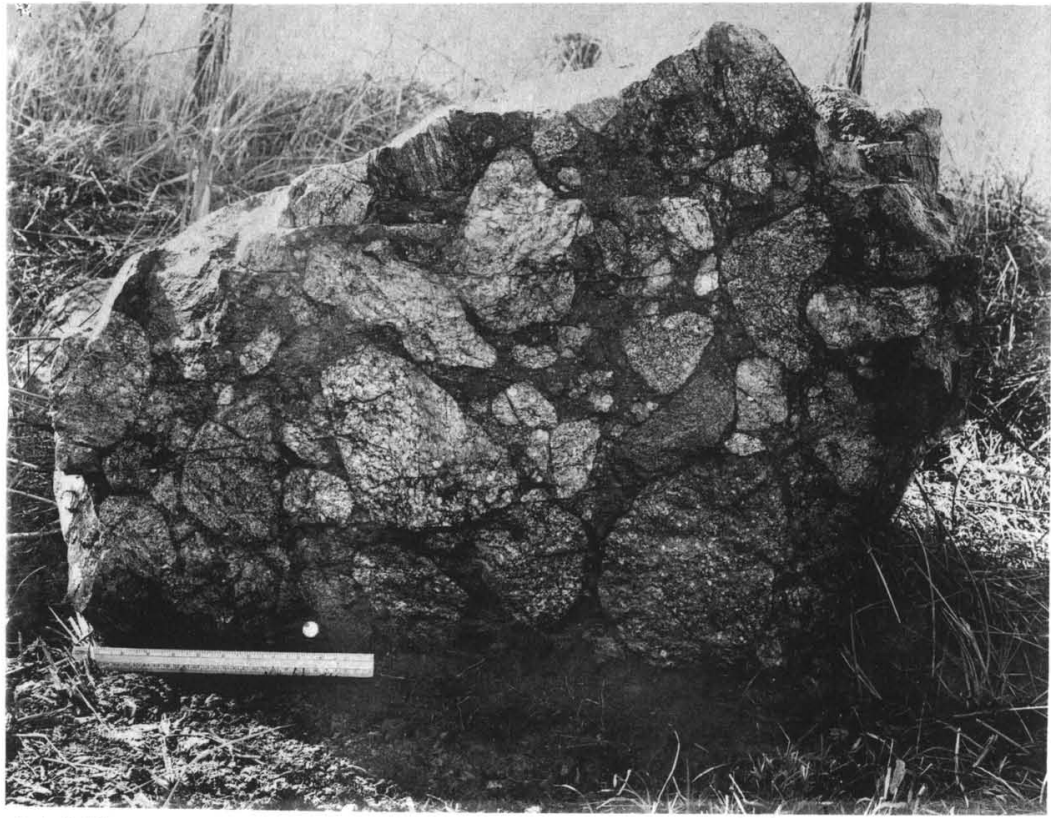




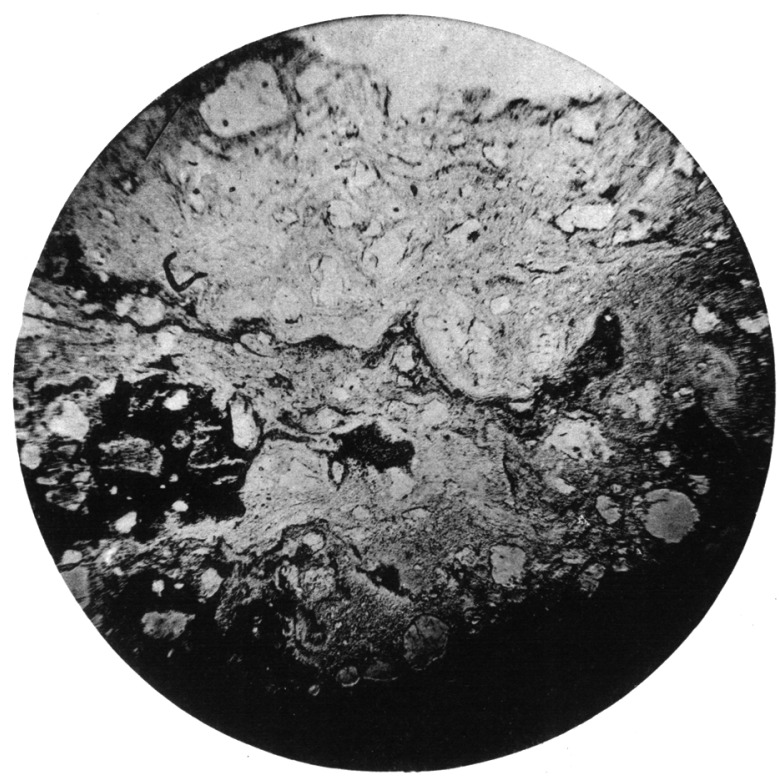

2. $\times 15$

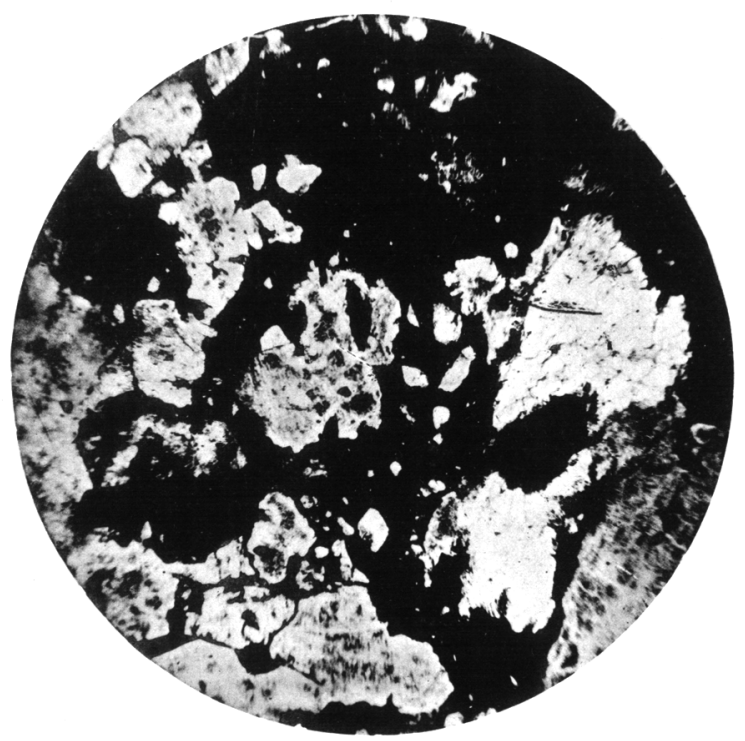

S.J.S., Photo.

Pseudotachylyte of Parius (O.f.S.). 

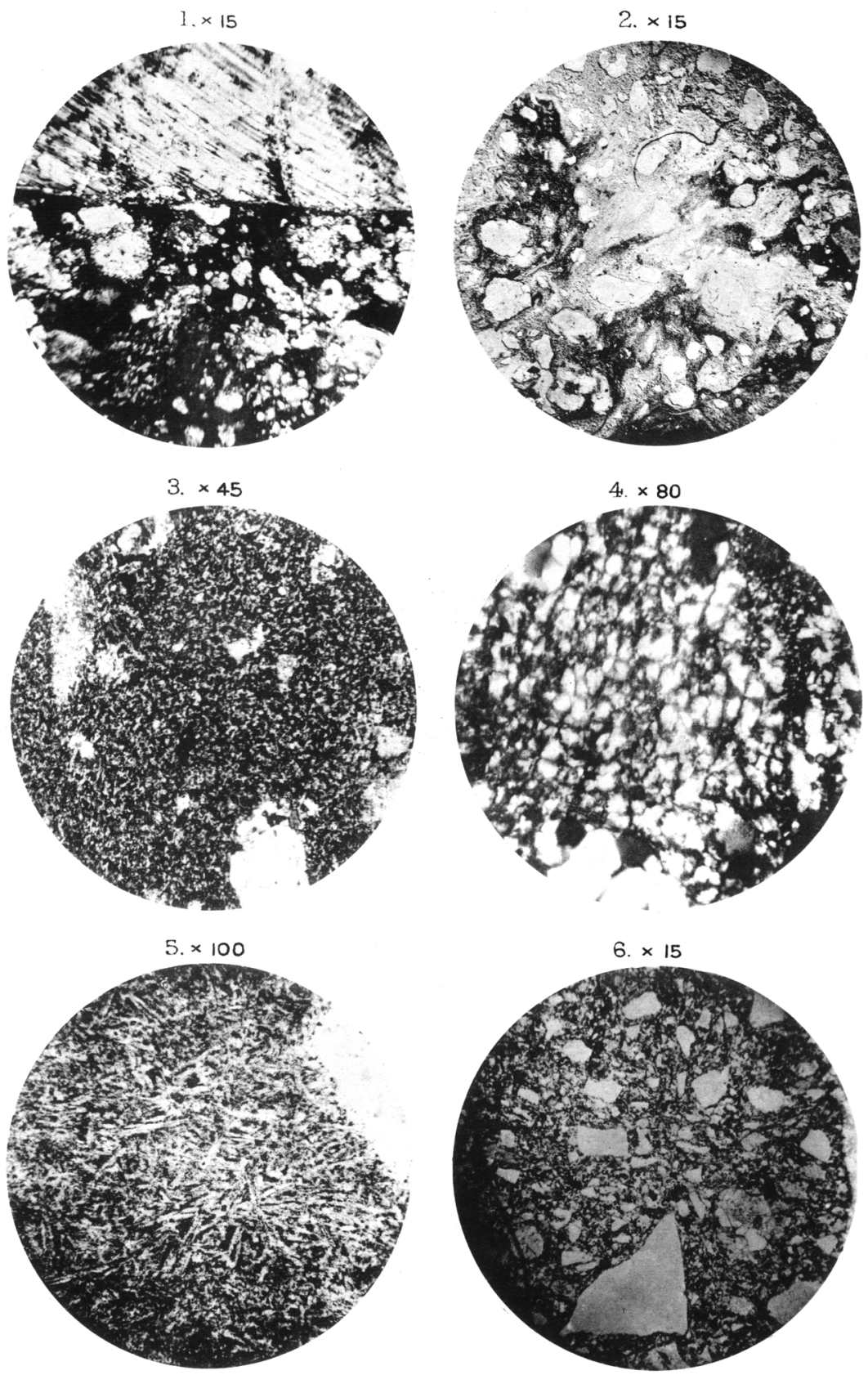